\title{
Langkahan Myth and Ritual in Javanese Weddings
}

\author{
Tiwi Purbandari ${ }^{1, *}$ Sutiyono ${ }^{1}$ \\ ${ }^{I}$ Program Pascasarjana, Universitas Negeri Yogyakarta, Yogyakarta, Indonesia \\ *Corresponding author. Email: tyangspuh.ads@gmail.com
}

\begin{abstract}
Myth is one of the people's beliefs. There are many kinds of myths in Java, one of which is the Myth in the Ritual of Langkahan which is done at a wedding. It is a tradition that started a long time ago but is still done by Javanese people now. This study is initiated due to the tradition done by the Javanese. Langkahan is a ritual done when younger siblings get married before their older sisters or brothers. The data in this study were collected through observation and interviews with the brides and bridegrooms, cultural experts, people done the ritual, and the researcher's experience. Langkahan as a ritual is done because of three feelings, one of which is lust-unlust. It is a feeling possessed by those whose younger siblings get married first. People tend to believe that there is some kind of effects of not doing this procession, so this procession is mostly done to avoid the effects. As traditions need to be preserved, Langkahan should still be done. It is a traditional cultural legacy from ancestors that serves as a symbol of the identity of an area. Moreover, it shows respect for older siblings whose younger siblings get married first.
\end{abstract}

Keywords: Myth, Tradition, Langkahan, Javanese wedding

\section{INTRODUCTION}

The culture that has been inherent in society and has been inherited a long time ago, will be increasingly conceptualized in people's life so that it becomes a belief that is difficult to get rid of. The beliefs that are still developing in a community are usually maintained through their local characteristics in which the local characters eventually become wisdom that is always held firmly by the community later.

Indonesia has a variety of cultural arts in its regions. Each region has traditional cultural arts with unique and artistic concepts in accordance with the region characters. The cultural arts are actually a priceless commodity of the Indonesian nation. The arts and can used as a reference for developing contemporary art and culture [3]. The values of local wisdom that still exist are usually still maintained by people. Something becomes a belief in the community because the culture has been attached and has become an essential thing in their life. Thus, the culture that has been passed down from generation to generation cannot be separated from one another. The existence of such a correlation between culture and society makes culture a very important thing for humans.
Focusing on the scope of society, there are complex behaviors including lifestyles, cultures, customs, beliefs, etc. Thus, cultures and customs are more essential in human life. In the scope of cultures, a custom and a belief are often referred to as a myth.

The term myth in Indonesian comes from the word "mythos" (Greek) which means the story of the gods, a fairy tale of the earth and everything in it [5]. Myth also means stories about gods, earth events and their contents, and beliefs in the supernatural world [5]. People believe that doing things against the myth is a sin. The existence of myths is closely related to customs that are still traditional in nature, especially to those who still believe in the dynamism teachings. Myths with the rules that have been passed cannot be simply dismissed, there will be many things that must be passed to change.

There are many myths in Javanese society. It is believed when Langkahan is not performed, bad things will happen to both the older sisters/brothers and their younger siblings. For example, if a younger sibling gets married before his older sibling then things will not be good for both of them. The older siblings are believed to find it difficult to find a mate, so will younger siblings who will not be at ease. Therefore, Langkahan ritual is held. 


\section{RESEARCH METHOD}

This study employed the qualitative method with a structuralism theory approach. It was conducted in Panjen Wedomartani village, in Ngemplak Sleman. This location was chosen because people from this village always do and preserve the tradition of doing Langkahan ritual.

The primary data were collected directly from the field through observation, documentation, and interview with people from Yogyakarta palace, wedding makeup artists, and the researcher's experience in doing the procession. Then, the secondary data were collected from books and internet websites.

\section{RESULT AND DISCUSSION}

\subsection{Langkahan Ritual in Javanese Society}

Langkahan comes from the word "langkah" which means steping up. Langkahan procession is done by a bride/bridegroom who gets married before her/his older siblings. Before siraman (bridal shower), the bride/bridegroom should ask her/his older siblings for permission. Besides, the bride/bridegroom should prepare gifts for them. The gifts are given to get blessings from older siblings.

Java area or kejawen is an area that until the Diponegoro war was still directly under the rule of the Surakarta kingdom and the kingdom of Dinia Agustia Artika Sari - Selametan Kematian in Jaweng Village, Boyolali District 154 Yogyakarta with Mangkunegaran and Pakualaman [1]. The life of the Javanese heavily depends on animism or beliefs from prehistoric times or before religions came to Indonesia [4].

Before holding this procession, the younger siblings should prepare a gift for their older brothers/sisters. The gifts are based on the wishes of the older siblings. Apart from giving gifts, several Langkahan offerings are also presented, such as tumpeng golong, grilled whole chicken, water with telon flowers, and wulung sugarcane. Each of the offerings has its own meaning.

Langkahan ritual is carried out when the bride/bridegroom gets married before his/her older siblings [2]. In the procession of Langkahan, the bride/bridegroom ask for their sibling's blessings. Thus, this procession is also a subtle effort to reduce or eradicate undue prejudice between families and friends. Palilah (sincere feelings) are shown by the older siblings to parents to make the parents feel relieved in holding the weddings.

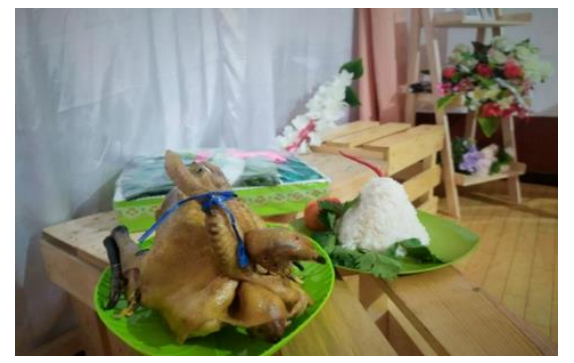

Figure 1. Langkahan offerings

The offerings prepared for the procession are explained below.

\subsubsection{Tumpeng golong}

It is a cone-shaped Javanese rice dish made of white rice. This dish is a symbol of nobility.

\subsubsection{A whole grilled chicken}

This dish is a symbol of goodness that will come ahead. The older siblings are expected to become noble people.

a. A bowl of red rose, white rose, and Cananga water. This offering is a symbol of freshness.

b. Wulung sugarcane is a symbol of perseverance in life.

The offerings should be given in the bridal shower because it has many symbols used to ask for blessings from older siblings.

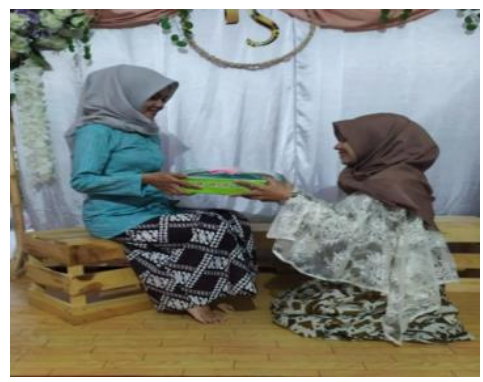

Figure 2. The bride gives the gifts to her older siblings

Langkahan procession is done in the following steps.

a. The bride or groom is guided by the elders to face the older sibling who is already seated in the designated place to offer her prayers, forgiveness, and blessings to the younger sibling.

b. Sabetan, the bride's or the groom's shoulders are hit with a broomstick consisting of only 7 sticks. 
Sabetan is a symbol that shows the older sibling blessings.

c. The bride or groom presents the gifts (a symbol of devotion) to their older siblings.

d. As a symbol of permission to the younger sibling, the younger sibling is guided to walk while holding a wulung sugar cane and grilled whole chicken. Then the younger sibling steps over the tumpeng three times. All of these are symbols of Rila Legawaning Nala, always showing the affection of older siblings for younger siblings.

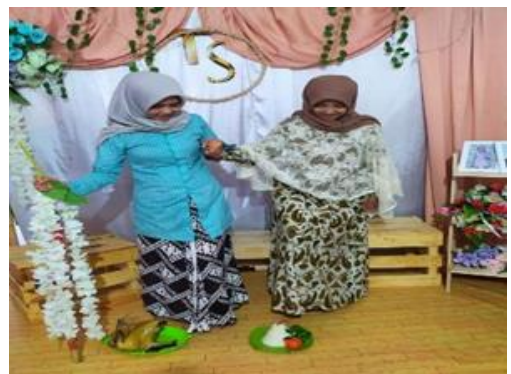

Figure 3. The older sibling guides the younger siblingstepping over the tumpeng

Based on the results of interviews with cultural expert Riyo Hamong Semito from Pawon Sokolanggen and a wedding makeup artist, Langkahan offerings may be adjusted based on the organizer so that there is no defined standard. However, there are still gifts asked by the older siblings because they should give their blessings.

\subsection{The Reasons Underlies Langkahan Ritual in Javanese Society}

The culture developed in Java is influenced by animist-dynamic and Hindu-Buddhist culture. Then, Islam arrived in Indonesia, and then there was acculturation of new cultures and sub-cultures. Cultures in Indonesia are resulted from a combination and convergence of previously existing cultures, one of which is Langkahan.

Myth is literally defined as a story or something that someone tells. In a broader sense, myth means a statement, a story, or a plot of a drama. It contains stories about the origin of the world as it is today, stories about nature, and events in the past. These stories are believed to be real and in a certain sense sacred.

In Langkahan ritual, there is a myth of Gugon Tuhon or prohibitions. If this prohibition is broken, the Javanese will get the consequences. Like the myth that is believed in this Langkahan ritual, bad things will happen to the brides/grooms and their older siblings if this ritual is not done. In other words, when a younger sibling gets married before her older sibling, things will not be good for both parties. The older siblings are believed to be difficult to find a mate, while the bride/groom will find problems too.

The researcher has experience Langkahan ritual. She feels relieved and happy because her sister is ready to be a wife. However, she thinks that people concern about her more than her sister during the preparation of the wedding. People in the neighborhood think that the researcher is not able to get a date.

Based on the explanation above, the researcher uses an empirical phase structuralism approach that elaborates three dimensions of feelings, namely Lustunlust (happy-displeased), Spannus-losuns (tenserelax), Erreguns-beruhigung (excited-calm). Those feelings are felt by people who have to hold Langkahan ritual and those who believe in the ritual.

The community believes in Langkahan tradition because it is a legacy from their ancestors that is now become a custom. Therefore, the researcher believes that Langkahan is done because of the three dimensions of human feelings involved, especially lust-unlust. This kind of feeling is felt by both the brides/grooms and their older siblings.

\subsection{Society Responses to Langkahan as a Part of Javanese Weddings}

This belief has developed in the community for a long time. When younger brothers/sisters get married before their older siblings, they will find difficulties in the future. Moreover, the older siblings will find it hard to get a mate. The younger siblings will also get an impression of being disrespectful to their siblings. There is also a belief that if people get married first before their older siblings, they will divorce later.

There are people who think that getting married before our older siblings is normal. However, there is a kind of ritual that must be done to prevent bad luck. Most people still believe in this myth, including in the neighborhood where the researcher lives. The researcher and her family conduct a Langkahan ritual. The ritual is done for the sake of love and respect for families. However, many people are starting to forget and leave this tradition.

Myth is literally defined as a story or something that someone tells. In a broader sense, myth means a statement, a story, or a plot of a drama. It contains stories about the origin of the world as it is today, stories about nature, events in the past. These stories are believed to be real and in a certain sense sacred. The culture developed in Java is influenced by animistdynamic and Hindu-Buddhist culture. Then, Islam has produced the acculturation of new cultures and subcultures. Cultures in Indonesia are resulted from a 
combination and convergence of previously existing cultures.

In Langkahan ritual, there is a myth of Gugon Tuhon or prohibitions. If this prohibition is broken, the Javanese will get the consequences. Like the myth that is believed in this Langkahan ritual, bad things will happen to the brides/bridegrooms and their older siblings. In other words, when a younger sibling gets married before her older sibling, things will not be good for both parties. The older siblings are believed to be difficult to find a mate, while the brides/grooms will find problems too.

Based response given by the community, they believe that this ritual is a tradition that needs to be preserved. They still believe in the myth and impacts that it brings. Therefore, Langkahan ritual will keep families away from the bad lucks believed by society.

\section{CONCLUSION}

Based on the results of the research, it is concluded that many people start to leave traditions, one of which is Langkahan ritual which is part of a wedding ceremony. The myth related to Langkahan is emerged due to three dimensions of feeling, especially lust-unlust. To those getting married and their older siblings, lust-unlust is the more dominant one.

Based on the response given by the community, they believe that this ritual is a tradition that needs to be preserved and they still believe in its consequences. Therefore, Langkahan is believed to keep families away from the bad lucks. This tradition needs to be preserved because it is a symbol of tradition passed over generations. This ritual also shows respect from brides/grooms for their older siblings, and it keeps the family harmonious. Therefore, the researcher concludes that Langkahan ritual should always be done to preserve the tradition and maintain a good relationship among siblings.

\section{REFERENCES}

[1] Laksono, Paschalis Maria. Tradisi dalam struktur masyarakat Jawa: kerajaan dan pedesaan: alih-ubah model berpikir Jawa [Traditions in the structure of Javanese society: kingdom and countryside: changing the Javanese thinking model]. Gadjah Mada University Press, 1985.

[2] Pringgawidagda, Suwarna. Tata upacara dan wicara: pengantin gaya Yogyakarta [Ceremony and speech: Yogyakarta style bride]. Kanisius, 2006.

[3] Suardana, I. Wayan. Struktur Rupa Topeng Bali Klasik. Imaji: Jurnal Seni dan Pendidikan
Seni 4.1 [Classical Balinese Mask Visual Structure. "Image: Journal of Arts and Arts Education 4.1]. (2006). DOI: https://doi.org/10.21831/imaji.v4i1.6703

[4] Sutiyono, Dr. Poros Kebudayaan Jawa [Javanese Culture Axis]. Graha Ilmu, 2013.

[5] Zulfahnur, Zuniar F., Sayuti Kurnia, and Zuniar Z. Adji. Teori Sastra [Literary Theory]. Jakarta: Dep-dikbud (1996). 